Yuzuncu Yil University
Journal of Agricultural Science

Research Article (Araştırma Makalesi)

Mitigation of Salinity Effects by Salicylic Acid Priming on Germination and Physiological Characteristics of Bitter Vetch (Vicia ervilia L.)

\author{
Sina Siavash MOGHADDAM ${ }^{*}$, Latifeh POURAKBAR ${ }^{2}$, Amir RAHIMI ${ }^{3}$, Faegheh JANGJOO ${ }^{4}$ \\ 1,3,4 Department of Plant Production and Genetics, Faculty of Agriculture and Natural Resources, Urmia \\ University, Urmia, Iran \\ ${ }^{2}$ Department of Biology, Faculty of Science, Urmia University, Urmia, Iran \\ ${ }^{1}$ https://orcid.org/0000-0001-8643-8991 ${ }^{2}$ https://orcid.org/0000-0002-2623-7394 ${ }^{3}$ https://orcid.org/0000-0002-8200-3103 \\ ${ }^{4}$ https://orcid.org/0000-0002-7308-1425 \\ *Corresponding author e-mail; ss.moghaddam@urmia.ac.ir
}

\begin{abstract}
Article Info
Received: 29.01.2020

Accepted: 27.01.2021

Online Published 30.03.2021

DOI: 10.29133 yyutbd.681949

Keywords

Cell death,

Germination parameters,

Hill reaction,

Salicylic Acid,

Salinity.
\end{abstract}

\begin{abstract}
Salinity is one of the most important environmental stresses affecting the growth and yield of the plants. The effect of salicylic acid (SA) on growth, germination, and some physiological traits of bitter vetch (Vicia ervilia L.) exposed to salinity was studied in a factorial experiment based on a randomized complete block design with three replications. The experimental treatments were composed of salinity at three levels of 0,50 and $100 \mathrm{mM}$ and SA priming at three rates of 0 , 0.1 and $0.2 \mathrm{mM}$. The results showed that as salinity was increased, germination and the related traits, seedling growth, and the Hill reaction rate were declined, but mean germination time and cell death were increased. SA application at the rates of 0.1 and $0.2 \mathrm{mM}$ improved these parameters as compared to control. At the salinity levels of 50 and $100 \mathrm{mM}$, SA rates of 0.2 and $0.1 \mathrm{mM}$ imposed the strongest effect on germination parameters and plant growth. At the salinity level of $100 \mathrm{mM}$, SA rate of $0.2 \mathrm{mM}$ was more effective on leaf relative water content, seedling fresh weight, root and stem length, and root and stem fresh weight. At different levels of salinity, $0.2 \mathrm{mM}$ SA increased the Hill reaction rate and cell death of bitter vetch. The application of SA under salinity stress for improvement of germination parameters, seedling growth, and physiological traits of bitter vetch could be recommended.
\end{abstract}

\title{
Salisilik Asit ile Priming Uygulamasının Acı Fiğ'ın (Vicia ervilia L.) Çimlenmesi ve Fizyolojik Özellikleri Üzerine Tuzluluk Etkilerinin Azaltılması
}

\section{Makale Bilgileri}

Geliș: 29.01.2020

Kabul: 27.01.2021

Online Yayınlanma 30.03.2021

DOI:10.29133/yyutbd.681949

\section{Anahtar kelimeler}

Hücre ölümü,

Çimlenme parametreleri,

Hill reaksiyonu,

Salisilik asit,
Öz: Tuzluluk, bitkilerin büyümesini ve verimi etkileyen en önemli çevresel streslerden biridir. Salisilik asitin (SA), tuzluluğa maruz kalan acı fiğin (Vicia ervilia L.), çimlenmesi, fide gelişimi ve bazı fizyolojik özellikleri üzerindeki etkisi, tesadüf bloklarında faktöriyel deneme modeline göre üç tekerrürlü olarak incelenmiştir. Çalışmada uygulamalar; 0, 50 ve 100 mM'lik üç seviyede tuzluluktan ve $0,0.1$ ve $0.2 \mathrm{mM}$ 'lik üç dozda SA priming uygulamasından oluşmuştur. Sonuçlar, tuzluluk arttıkça çimlenme ve ilgili özelliklerin, fide büyümesinin ve Hill reaksiyon hızının azaldığını, ancak ortalama çimlenme süresinin ve hücre hasarının arttığını göstermiştir. SA'nın 0.1 ve $0.2 \mathrm{mM}$ uygulamaları, kontrole kıyasla bu parametreleri iyileştirmiştir. Tuzluluğun 50 ve 100 mM'lık ve SA'nın 0.2 ve 0.1 mM'lik seviyeleri çimlenme parametreleri ve bitki büyümesi üzerinde en güçlü etkiyi sağlamıştır. $100 \mathrm{mM}$ tuzluluk seviyesinde, 0.2 mM'lik SA oranı, yaprak nispi 

üzerinde daha etkili olmuştur. Farklı tuzluluk seviyelerinde $0.2 \mathrm{mM}$ SA, Hill reaksiyon hızını ve acı fiğin hücre hasarını arttırmıştır. Tuzluluk stresi altında SA uygulaması, acı fiğin çimlenme parametrelerinin, fide gelişiminin ve fizyolojik özelliklerinin iyileştirilmesi bakımından önerilebilir.

\section{Introduction}

Bitter vetch (Vicia ervilia $\mathrm{L}$ ) is one of the oldest domesticated plants from the family Fabaceae. Bitter vetch is a very old grain legume in the Mediterranean region whose cultivation dates back to 10 000 years ago. It is grown for grains and dry forage (Abdullah et al., 1999; Sadeghi et al., 2009). Salinity is one of the stresses that limit crop production. Salinity stress occurs when the amount of salts accumulated in the root zone is beyond the tolerance of plants, which disrupts the vital processes of the plant, such as nutrient uptake and mobilization, transpiration, and photosynthesis. Salinity influences the biochemical and physiological processes and the biosynthesis of primary and secondary metabolites of plants (Hendawy and Khalid, 2005). Salinity reduces the activity of $\alpha$-amylase by reducing the amount of bioactive gibberellin content, which in turn prevents seeds germination (Liu et al., 2018). Salinity stress causes the generation of reactive oxygen species (ROS) and increases membrane permeability of the cells; then, in addition to oxidative damage by ROS, this results in the build-up of some proteins including heat shock proteins, chaperones, and other detoxifying proteins (Sudhakar et al., 2001).

To preserve turgor under salinity stress, plants produce compounds that make intra-cellular water potential more negative so as to enable the plant to keep the turgor pressure. Known as osmolytes, these compounds are generated by all living organisms. Osmolytes have a very high solubility. However, their molecular weight is low, and at high concentrations, they are not toxic to cells and do not disrupt the natural reactions of the cell (Ashraf and Foolad, 2007).

The application of germination improving techniques (priming) is an approach to improve germination and seedling establishment under environmental stresses. The ultimate goal of seed priming is their partial imbibition so that seeds pass through the first (physical uptake) and second (initiation of biochemical processes and hydrolysis of sugars) stage of germination, but they are inhibited from the third stage (sugar consumption by embryo and rootlet growth) (Bradford, 1995).

Salicylic acid (SA, o-hydroxybenzoic acid) is a phenolic compound that is involved in seed growth and development and germination, photosynthesis, glycolysis, interaction with other organisms, and plant responses to environmental stresses (Popova et al., 1997; Hayat et al., 2010). It acts as a signal transmitter molecule and affects many of the physiological and biochemical processes of the plant under stress and non-stress conditions. These processes include seed germination and vigor, seedlings establishment, cell growth and expansion, as well as the activity of enzymes, the synthesis of flavonoids and photosynthesis apparatus in detrimental environmental conditions (Vlot et al., 2009; Akbulut et al., 2018). Salicylic acid augments the activity of the enzyme phenylalanine ammonia lyase. The increased activity of this enzyme entails the increase in the synthesis and accumulation of phenolic compounds, and finally, phenolic compounds with the antioxidant properties enhance resistance to biotic and abiotic stresses (Eraslan et al., 2007). Gautam and Singh (2009) concluded that SA at high rates can mitigate the adverse impacts of salinity and osmotic stresses induced by the build-up of ROS generation during photosynthesis and germination of maize. Application of $\mathrm{NaCl}$ reduced all germination traits in comparison with control. Whereas application of SA enhanced germination percentage by $13.05 \%$, vigor index by $68.60 \%$, mean germination time by $39.74 \%$ compared to respective $\mathrm{NaCl}$ treatments (Alamri et al., 2018). Hamid et al. (2010) reported that SA priming of wheat seeds under salinity stress resulted in the production of more vigorous and larger seedlings and enhanced chlorophyll, dissolved sugars and proteins content of the plant.

This study aimed to explore the effect of salicylic acid application on alleviating the impacts of salinity stress on germination components, physiology, and growth parameters of bitter vetch. 


\section{Material and Methods}

\subsection{Germination and growth parameters}

The present study was carried out in the laboratories of the Departments of Agriculture and Biology at Faculty of Agronomy of Urmia University (Iran) in 2016, as a factorial experiment based on a randomized complete block design with three 50 -fold replications. The experimental treatments included priming with salicylic acid (SA) at three levels of $0,0.1$ and $0.2 \mathrm{mM}$, and $\mathrm{NaCl}$ at three levels of 0,50 and $100 \mathrm{mM}$. The seeds were first disinfected with sodium hypochlorite (5\%) for 2 minutes, and then they were rinsed with distilled water. For priming, the seeds were soaked in SA at the intended concentration in darkness at $25^{\circ} \mathrm{C}$ for 8 hours. Then, to remove their excess moisture, they were airdried at room temperature for 24 hours. To test the germination, the seeds were placed between the papers in Petri dishes with a mouth diameter of $9 \mathrm{~cm}$. Finally, the Petri dishes were placed in a germinator at $25^{\circ} \mathrm{C}$. During the supply of moisture requirement of germination, the seeds were treated with salinity levels as mentioned. To evaluate germination parameters, the seeds were counted on a specific time every day until the number of germinated seeds in each replication reached a plateau for three consecutive days. The criterion for germination was the exit of rootlet for $2 \mathrm{~mm}$ or more. On day 7, five seedlings were sampled from each replication to record their seedling length, rootlet length, plumule length, and seedling fresh and dry weight. After the fresh weight of the seedlings was recorded, they were oven-dried at $72^{\circ} \mathrm{C}$ for 48 hours to measure their dry weight. The data of five samples were averaged to supply the final data.

The seedlings remained in the Petri dishes were employed to study physiological parameters including leaf relative water content, the Hill reaction, cell death, and post-harvest length and weight parameters of the bitter vetches. Four seedlings were sampled from each replication and were planted in pots containing perlite. Then, they were placed in a growth chamber at light/dark regime of 16/8 hours. The seedlings in the pots were irrigated with distilled water every other day and were fed on Hoagland solution containing 0,50 or $100 \mathrm{mM} \mathrm{NaCl}$ as per the experimental design. To measure the post-harvest length and weight parameter, the traits of root and stem length, root and stem fresh weight, and root and stem dry weight (after oven-drying at $72^{\circ} \mathrm{C}$ for 48 hours) were measured 15 days later.

\subsection{Leaf relative water content}

To measure the relative water content (RWC) of leaf, $0.2 \mathrm{~g}$ of a fully developed leaf was sampled from each replication, and a section of $1 \mathrm{~cm}^{2}$ was cut from the middle part of the blade. Then, the leaf discs were placed in capped Petri dishes containing distilled water and were placed in darkness at $4{ }^{\circ} \mathrm{C}$ for 16 hours. After some time, the leaves were taken out of the distilled water to measure their saturated weight. So, they were placed between two filter papers to get rid of their excessive moisture. Immediately after that, their saturated weight was measured. After their turgid weight was recorded, the leaf sections were oven-dried at $70^{\circ} \mathrm{C}$ for 48 hours to find out their dry weight.

\subsection{Hill reaction measurement}

The Hill reaction was measured by Patsikka et al. (2001) procedure for which first, $0.2 \mathrm{~g}$ of fresh leaf tissue was cut and crushed in $3 \mathrm{~mL}$ of phosphate buffer with $\mathrm{pH} 7$ that was cooled in the freeze. The filtered extract was centrifuged at $10000 \mathrm{rpm}$ for 2 minutes and the supernatant was removed. Then, 3 $\mathrm{mL}$ of cold phosphate buffer was poured on the sediment of the centrifuge and the sediment was suspended with a brush gently. After that, $0.5 \mathrm{~mL}$ of the solution was added to $2 \mathrm{~mL}$ of cold phosphate buffer and $0.2 \mathrm{~mL}$ of dichlorophenolindophenol (DCPIP). Immediately, its absorption was read at 550 $\mathrm{nm}$ with a spectrophotometer. Then, the tube was exposed to a 150-W lamp for 20 seconds and its absorption was re-read. This was repeated until five minutes as far as $\mathrm{T}=100$ was realized. Dichlorophenolindophenol reduction ate was calculated as a percent of control. 


\subsection{Cell death measurement}

Cell death is a measure of damage to the cell membrane. It was measured by Baker and Monck (1994) method using absorption of the Evans blue reagent. Three 1-cm pieces from root tips were placed in the Evans blue reagent $0.025 \%$ in water for 30 minutes. Then, the pieces were rinsed for 15 minutes. The samples were crushed in $1 \mathrm{~mL}$ of methanol solution. The extract was placed in a Bain-marie at $50^{\circ} \mathrm{C}$ for 15 minutes and then, it was centrifuged at $14000 \mathrm{rpm}$ for 15 minutes. The absorption was read at $600 \mathrm{~nm}$ with a spectrophotometer and the cell death was stated as a percent of control.

$$
\text { Final germination percentage }=\frac{\text { Number of germinated seeds }}{\text { Total number of seeds }}
$$

Germination speed index (GSI) was estimated by AOSA (1983) as follows:

$$
\text { GSI }=\frac{\text { No. germinated seeds at first counting }}{\text { First day of counting }}+\cdots+\frac{\text { No. germinated seeds at final counting }}{\text { Final day of counting }}
$$

Mean germination time (MGT) was obtained as reported by Ellis and Roberts (1981):

$$
\operatorname{MGT}=\frac{\sum \mathrm{D}_{\mathrm{n}}}{\sum \mathrm{n}}
$$

Seedling vigor index (SVI) was calculated according to Abdel-Baki and Anderson (1973), using the following equation:

$$
\text { SVI }=\frac{\text { Seedling length }(\mathrm{cm}) \times \text { germination percentage }}{100}
$$

Relative water content was calculated according to Smart and Bingham (1974), formula as follow:

$$
\text { RWC }=\frac{\text { Fresh weight }- \text { dry weight }}{\text { Saturated weight }- \text { dry weight }} \times 100
$$

Experimental data were analyzed with MSTAT-C software package, and the means were compared with Duncan's Test at $\mathrm{P}<0.05$. Also, the graphs were drawn in MS-Excel software package.

\section{Results}

Analysis of variance (ANOVA) shows that salinity, SA, and their interactions influenced all studied parameters, except root fresh weight and stem fresh weight, significantly at $\mathrm{p}<0.01$ and $\mathrm{p}<0.05$ levels. As salinity was increased from 0 to $100 \mathrm{mM}$, the measured parameters were decreased whereas the application of SA increased them significantly (Table 1 and 2).

\subsection{Germination and growth parameters}

According to the results of ANOVA, germination percentage was significantly $(\mathrm{p}<0.01)$ influenced by salinity, SA, and salinity $\times$ SA. This trait was decreased by salinity. As salinity was increased, a significant change happened in final germination percentage of bitter vetch seeds so that among seeds unprimed with SA, the highest germination percentage of $48.67 \%$ was related to those exposed to $0 \mathrm{mM}$ salinity and the lowest one (46.33\%) was obtained from those exposed to $100 \mathrm{mM}$ salinity. The application of SA at the rates of 0.1 and $0.2 \mathrm{mM}$ increased this trait in plants exposed to salinity stress, but these two rates of SA did not differ significantly to one another and were ranked in the same statistical group (Figure 1). Mean germination time was affected by salinity and SA. The simple effect of salinity and SA and their interactions were significant at $\mathrm{p}<0.01$ level on this trait (Table 1 ). Salinity increased mean germination time and thereby postponed the germination of bitter vetch seeds. 
A look at the interaction between salinity and SA shows that SA reduced mean germination time. The highest mean germination time (2.16 day) was observed in plants treated with $100 \mathrm{mM}$ salinity and the lowest one (1.30 day) was seen in plants treated with $0.2 \mathrm{mM} \mathrm{SA}$ under no salinity stress (Figure 1). The increase in salinity resulted in the loss of germination speed and the increase in mean germination time.

According to the results, germination speed index was affected by salinity, SA and their interaction at $\mathrm{p}<0.01$ level (Table 1). As salinity was increased, germination index was reduced from $\left(29.75 \%\right.$.day $\left.^{-1}\right)$ at $0 \mathrm{mM}$ salinity level to $\left(22.28 \%\right.$.day $\left.^{-1}\right)$ at $100 \mathrm{mM}$ salinity level. This trait was improved with the application of 0.1 or $0.2 \mathrm{mM} \mathrm{SA}$. These two rates of SA did not show significant differences between salinity levels of 0 and $50 \mathrm{mM}$ so that SA rate of $0.2 \mathrm{mM}$ had the highest impact at the salinity levels of $0 \mathrm{mM}$ and $50 \mathrm{mM}$ resulting in germination index of (42.32 and $32.94 \%$.day ${ }^{-1}$ respectively). SA rates did not differ significantly at the salinity level of $100 \mathrm{mM}$ so that they were all placed in the same statistical group (Figure 1). ANOVA results revealed that the simple and interactive effects of salinity and SA were significant on seedling vigor at $\mathrm{p}<0.01$ level (Table 1 ). Higher salinity level was related to lower seed vigor. The lowest seed vigor (298.80) was observed in unprimed seeds exposed to $100 \mathrm{mM}$ salinity stress, and the highest one (603.30) was observed in unstressed seeds. SA priming of the seeds improved seed vigor considerably. The highest seed vigor at all salinity levels was obtained from seeds primed with $0.2 \mathrm{mM}$ SA so that it was $1009.00,754.70$ and 465.70 at the salinity levels of 0,50 and $100 \mathrm{mM}$, respectively (Figure 1).

The simple and interactive effects of salinity and SA were significant $(\mathrm{p}<0.01)$ on these traits (Table 1). The highest radical, plumule, and seedling length (8.38, 11.80 and $20.19 \mathrm{~cm}$, respectively) were obtained from SA rate of $0.2 \mathrm{mM}$ at $0 \mathrm{mM}$ salinity level and the lowest ones (3.16, 3.28 and 6.44 $\mathrm{cm}$, respectively) were related to unprimed seeds (Figure 1).

Seedling fresh and dry weight was influenced by salinity and SA significantly at $\mathrm{p}<0.01$ level (Table 1). Salinity entailed the loss of fresh and dry weight as compared to control so that the highest decline was observed at $\mathrm{NaCl}$ level of $100 \mathrm{mM}$ in which fresh and dry weight was reduced by (98.40 and $15.73 \mathrm{mg}$, respectively). In contrast, SA priming improved these two traits in seeds exposed to stress. At the salinity level of $50 \mathrm{mM}$, fresh and dry weight was maximized to (84.80 and $12.93 \mathrm{mg}$, respectively) when $0.2 \mathrm{mM}$ SA was applied. At the salinity level of $100 \mathrm{mM}$, the fresh and dry weight of seedlings that grew from seeds primed with $0.2 \mathrm{mM}$ reached (71.93 and $8.13 \mathrm{mg}$, respectively). (Figure, 1). The loss of seedling fresh weight may be related to the loss of the water content of seedling tissue.

\subsection{Relative water content}

Relative water content (RWC) was significantly affected by salinity and SA at $\mathrm{p}<0.01$ level and by their interaction at $\mathrm{p}<0.05$ level (Table 1 ). Under no salinity conditions, SA rate of $0.2 \mathrm{mM}$ resulted in the highest RWC of \%81.23. Under salinity levels of 50 and $100 \mathrm{mM}$, the application of 0.2 mM SA improved RWC to \%74.97 and \%69.06, respectively (Fgure 2).

\subsection{Hill reaction}

According to Figure 1, different levels of salinity differed significantly in the Hill reaction. The increase in the salinity levels entailed a significant loss of the Hill reaction. The lowest rate of the Hill reaction was $64.78 \%$ obtained from unprimed seeds exposed to $100 \mathrm{mM}$ salinity. SA application improved the rate of this reaction. The highest rate was $125.86 \%$ obtained from the application of 0.2 mM SA under no salinity stress conditions. At the salinity levels of 50 and $100 \mathrm{mM} \mathrm{NaCl}$, the application of $0.2 \mathrm{mM}$ SA increased the rate of the Hill reaction to $95 \%$ and $82.22 \%$, respectively as compared to control (Figure 2).

\subsection{Cell death}

The results show that cell death was aggravated remarkably with the increase in the salinity level to $100 \mathrm{mM}$. The highest rate of cell death (87\%) was obtained from unprimed seedlings exposed to $100 \mathrm{mM}$ salinity. The lowest rate was $49.77 \%$ obtained from the application of $0.2 \mathrm{mM}$ SA under no 
salinity stress. At the salinity level of $50 \mathrm{mM}, 0.1$ and $0.2 \mathrm{mM}$ SA reduced cell death from $70 \%$ of control to 68.5 and 56.1\%, respectively. At the salinity level of $100 \mathrm{mM}$, cell death was decreased to 75.87 and $67.7 \%$ as compared to control (87\%) when 0.1 and $0.2 \mathrm{mM} \mathrm{SA}$ was applied (Figure 2).

\subsection{Post germination}

The simple effect of salinity and SA was significant on root and stem length at $\mathrm{p}<0.01$ level and the interaction between salinity and SA was significant at $\mathrm{p}<0.05$ level (Table 2 ). The lowest root length $(19.03 \mathrm{~cm})$ and stem length $(22.61 \mathrm{~cm})$ were obtained from seedlings exposed to $100 \mathrm{mM}$ salinity and the highest root length $(29.96 \mathrm{~cm})$ and stem length $(34.96 \mathrm{~cm})$ were obtained from those primed with $0.2 \mathrm{mM}$. SA application at salinity stress improved these traits. At the salinity level of $50 \mathrm{mM}$, the application of $0.2 \mathrm{mM} \mathrm{SA}$ increased root length from 14.86 to $20.56 \mathrm{~cm}$ and stem length from 17.74 to $23.83 \mathrm{~cm}$. At the salinity level of $100 \mathrm{mM}$, seedlings primed with $0.1 \mathrm{mM}$ SA exhibited an increase in root length from 9.74 to $16.60 \mathrm{~cm}$ and stem length from 13.30 to $19.16 \mathrm{~cm}$ (Figure 2).

Salinity and SA influenced root fresh and dry weight significantly at $\mathrm{p}<0.01$ level, whilst their interaction was significant at $\mathrm{p}<0.05$ for fresh weight but insignificant for dry weight (Table 2). Salinity resulted in a significant difference with control by reducing root fresh weight and subsequently, its dry weight. Root fresh weight was decreased from $0.13 \mathrm{~g}$ in control to $0.02 \mathrm{~g}$ in plants treated with $100 \mathrm{mM}$ salinity. On the other hand, SA application increased root fresh weight. SA at $0.2 \mathrm{mM}$ rate was more effective on root fresh weight than $0.1 \mathrm{mM}$ SA. In plants exposed to 50 and $100 \mathrm{mM}$ salinity, the highest root fresh weight were 0.12 and $0.08 \mathrm{~g}$, respectively obtained from the application of $0.2 \mathrm{mM} \mathrm{SA}$. Root dry weight was also declined with the increase in the salinity level and in contrast, SA enhanced this trait (Figure 2,Table 3).

Stem fresh weight was affected by SA and salinity at $\mathrm{p}<0.01$ level and by their interaction at $\mathrm{p}<0.05$ level (Table 2). SA priming resulted in higher stem fresh and dry weight under various salinity levels. SA rate of $0.2 \mathrm{mM}$ had the strongest effect on stem fresh weight in seedlings treated with 50 and $100 \mathrm{mM}$ salinity so that stem fresh weight was increased to 0.47 and $0.27 \mathrm{~g}$ at these salinity levels, respectively (Figure 2). 
Table 1. Analysis of variance for the effect of salinity and salicylic acid (SA) on germination and physiological traits of Vicia ervilia

\begin{tabular}{|c|c|c|c|c|c|c|c|c|c|c|c|}
\hline Treatment & $\mathrm{df}$ & FGP (\%) & MGT (day) & GSI (\%.day $\left.{ }^{-1}\right)$ & SVI & RWC (\%) & $\mathrm{RL}(\mathrm{cm})$ & PL (cm) & $\mathrm{SL}(\mathrm{cm})$ & SFW (mg) & SDW (mg) \\
\hline Salinity & 2 & $1.815^{* *}$ & $0.383^{* *}$ & $228.580^{* *}$ & $349362.177^{* *}$ & $289.805^{* *}$ & $15.098^{* *}$ & $63.437^{* *}$ & $136.923^{* *}$ & $1430.173^{* *}$ & $70.581^{* *}$ \\
\hline SA & 2 & $15.815^{* *}$ & $0.276^{* *}$ & $167.090^{* *}$ & $230411.981^{* *}$ & $223.611^{* *}$ & $16.492^{* *}$ & $23.983^{* *}$ & $80.243^{* *}$ & $1828.138^{* *}$ & $28.114^{* *}$ \\
\hline Salinity $\times$ SA & 4 & $1.315^{* *}$ & $0.032^{* *}$ & $13.935^{* *}$ & $19367.066^{* *}$ & $1.329^{*}$ & $1.651^{* *}$ & $3.202^{* *}$ & $7.818^{* *}$ & $31.478^{* *}$ & $2.852^{* *}$ \\
\hline Error & 18 & 0.185 & 0.003 & 0.816 & 703.921 & 0.353 & 0.156 & 0.183 & 0.26 & 4.019 & 0.3 \\
\hline CV (\%) & - & 0.88 & 2.96 & 2.98 & 4.26 & 0.85 & 6.79 & 6.28 & 4.04 & 2.77 & 5.07 \\
\hline
\end{tabular}

** and * show significant at $\mathrm{p}<0.01$ and $\mathrm{p}<0.05$ levels, respectively.

(FGP: final germination percentage, MGT: mean germination time, GSI: germination speed index, SVI: seedling vigor index, RWC: relative water contetn, RL: radicle length, PL: plumule length, SL: seedling length, SFW: seedling fresh weight, SDW: seedling dry weight)

Table 2. Analysis of variance for the effect of salinity and salicylic acid (SA) on germination and physiological traits of Vicia ervilia

\begin{tabular}{llllllll}
\hline Treatment & df & Root LE $(\mathrm{cm})$ & Stem LE $(\mathrm{cm})$ & Root FW $(\mathrm{g})$ & Stem FW $(\mathrm{g})$ & Root DW $(\mathrm{g})$ \\
\hline Salinity & 2 & $252.095^{* *}$ & $363.248^{* *}$ & $0.058^{* *}$ & $0.242^{* *}$ & $0.002^{* *}$ \\
SA & 2 & $138.559^{* *}$ & $148.069^{* *}$ & $0.021^{* *}$ & $0.138^{* *}$ & $0.001^{* *}$ \\
Salinity $\times$ SA & 4 & $7.297^{*}$ & $10.201^{*}$ & $0.004^{* *}$ & $0.005^{*}$ & $0.003^{*}$ \\
Error & 18 & 2.617 & 2.815 & 0 & 0.001 & $0.001^{\text {ns }}$ & 0 \\
CV $(\%)$ & - & 8.85 & 7.69 & 15.18 & 9.85 & 0.001 \\
\hline
\end{tabular}

** and * show insignificant at $\mathrm{p}<0.01$ and $\mathrm{p}<0.05$ levels, respectively, ns: not significant

(Root LE: root length; Stem LE: stem length; Root FW: root fresh weight; Root DW: root dry weight).

Table 3. Mean comparision of the main effect of salinity and SA on root and stem dry weight of vicia ervilia

\begin{tabular}{ccc}
\hline Factor & Root DW (g) \\
\hline Salinity & \\
$0 \mathrm{mM}$ & $0.04^{\mathrm{a}^{*}}$ & $0.08^{\mathrm{a}}$ \\
$50 \mathrm{mM}$ & $0.02^{\mathrm{a}}$ & $0.05^{\mathrm{ab}}$ \\
$100 \mathrm{mM}$ & & $0.03^{\mathrm{b}}$ \\
Salicylic acid & & \\
$0 \mathrm{mM}$ & $0.01^{\mathrm{b}}$ & $0.02^{\mathrm{b}}$ \\
$0.1 \mathrm{mM}$ & $0.04^{\mathrm{a}}$ & $0.06^{\mathrm{ab}}$ \\
$0.2 \mathrm{mM}$ & $0.07^{\mathrm{a}}$ \\
\hline
\end{tabular}

*Different letters show significant differences at $\mathrm{p}<0.01$ level. 

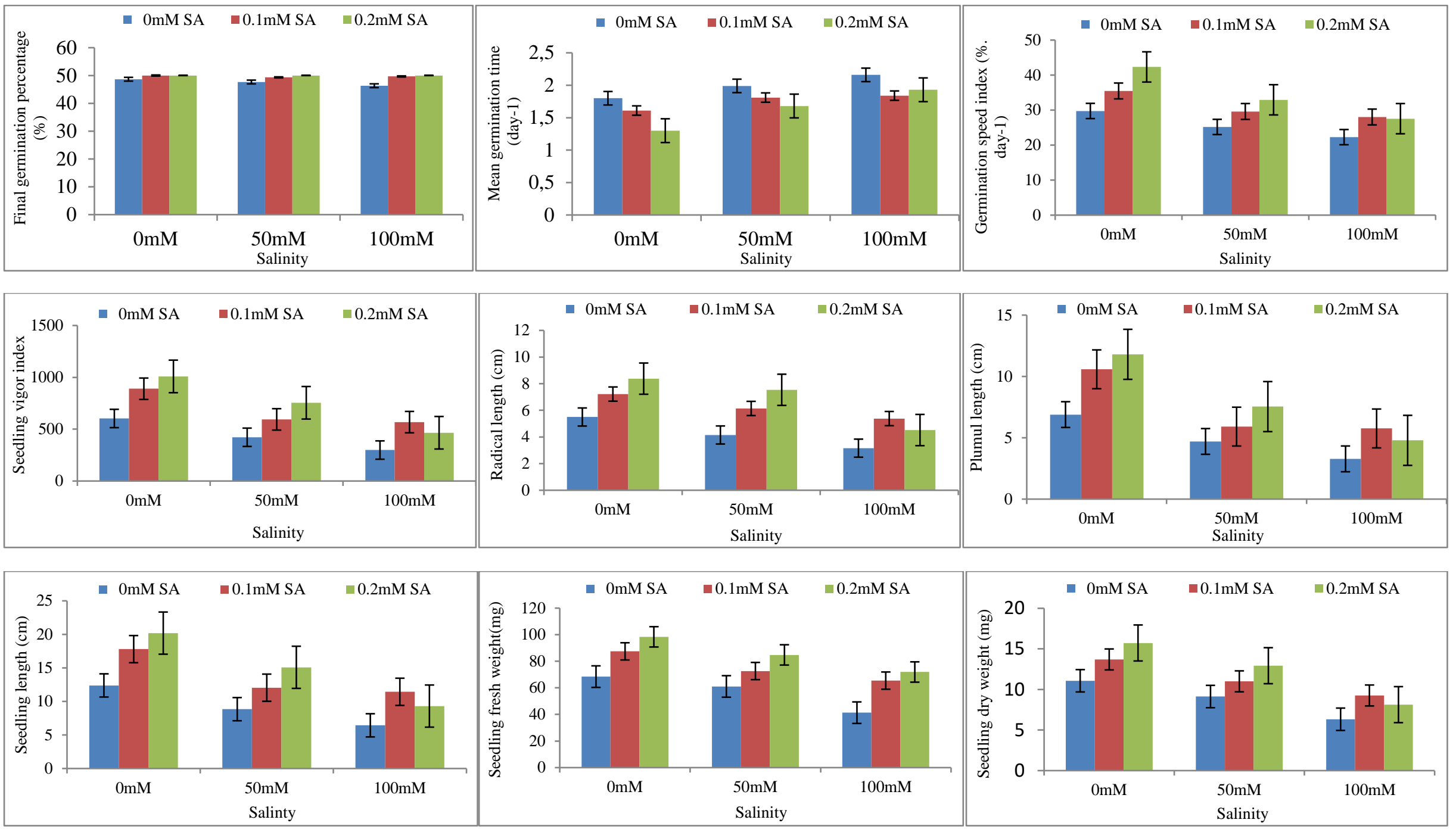

Figure 1. The effect of salinity and SA on germination and growth parameters of bitter vetch. 

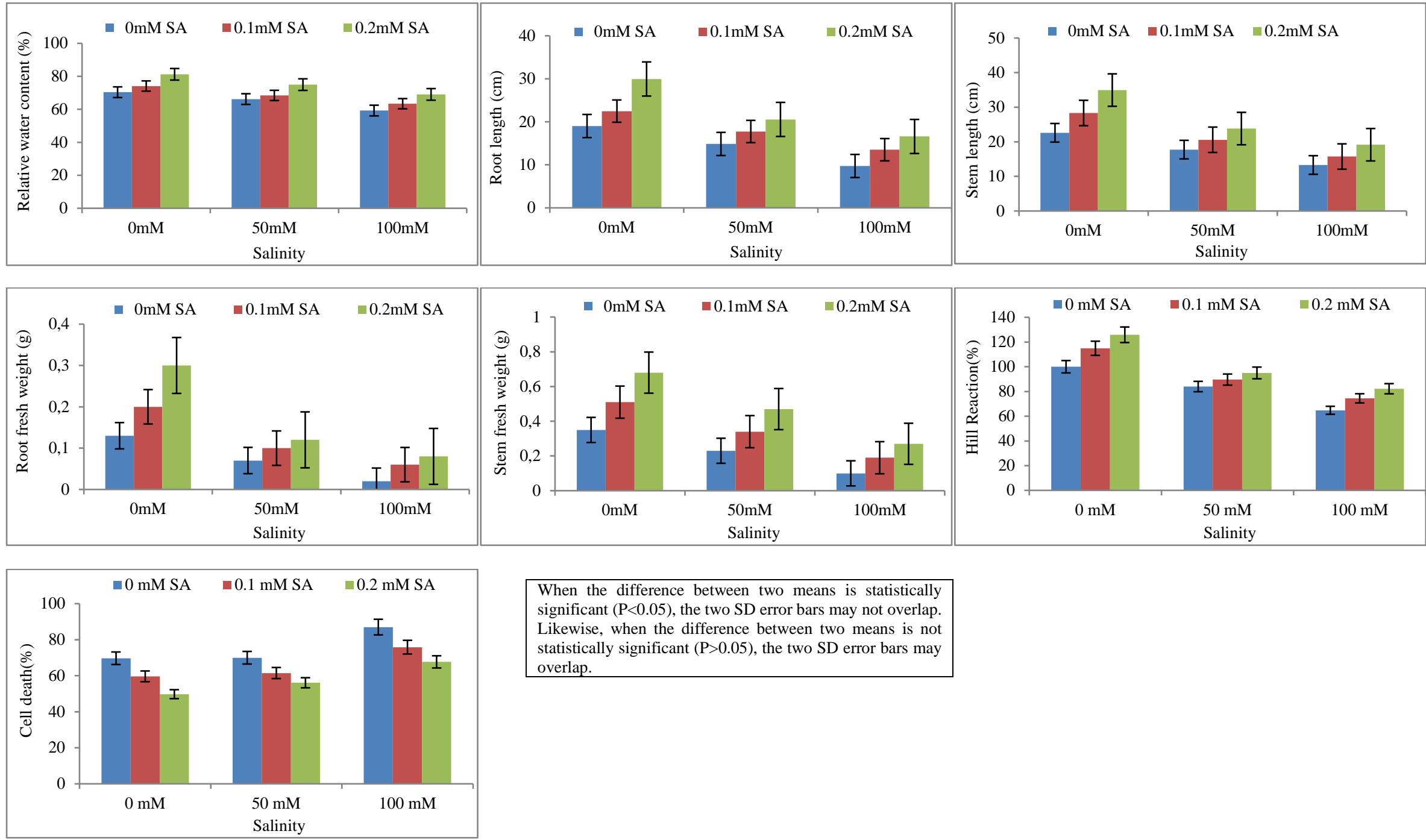

When the difference between two means is statistically

significant $(\mathrm{P}<0.05)$, the two SD error bars may not overlap.

Likewise, when the difference between two means is not

statistically significant $(\mathrm{P}>0.05)$, the two SD error bars may overlap.

Figure 1. The effect of salinity and SA on growth parameters, Hill reaction and Cell death of bitter vetch (continued). 


\section{Discussion and Conclusion}

The loss of germination percentage with the increase in salinity may be related to the loss of water uptake by seeds under salinity stress, which reduces physiological and metabolic processes so that plants suffer from nutrients unavailability and the germination is impaired (Ashraf and Waheed, 1990). It seems that SA alleviates the toxic and destructive effects of salinity and increases germination by influencing the antioxidant system. In a study on the effect of salinity on germination speed and percentage and the growth of rootlet and plumule in several plants, Dai et al. (2009) showed that the effect of salinity at germination stage was a reliable test of a plant's tolerance because salinity reduced germination percentage and speed as well as rootlet and plumule growth. The loss of mean germination time in primed seeds is likely to be related to the rate of cell division in primed seeds. Due to the synthesis of DNA, RNA and proteins during seed priming, most physiological stages are completed and seeds are ready to germinate (Brancalion et al., 2008; Foti et al., 2008). De and Kar (1994) reported that when water uptake is disrupted in seeds or when it goes on slowly, the metabolic activities of germination in seeds occur slowly and so, more time is required for the roots to emerge and germination speed decreases. The loss of the studied germination parameters can be related to the loss of the amount and rate of initial water uptake and the adverse impact of low osmotic potentials and ion toxicity on biochemical processes and catabolic (enzymatic hydrolysis of seed reserves) and anabolic (the fabrication of new tissues by using hydrolysis materials of the first stage) stages (Shamsadin Saeid et al., 2008). Shakirova et al. (2003) have been reported that the desirable effect of SA on the improvement of seed vigor under no stress conditions is accompanied with the increased level of IAA and ABA hormones. Shakirova et al. (2003) underline that SA mechanism in increasing stem length, cell division, and elongation in plants was related to such compounds as auxin. Seeds germinated in saline media produce shorter plumules and radicals and the inhibitory effect of $\mathrm{NaCl}$ is stronger than other salts on the emergence of embryo tissues as reported in literature (Khan and Ungar, 1985; Katergi et al., 1994). This is consistent with Sharma et al. (2004) who reported the decrease in seedling fresh weight when salinity level was increased from 0 to 20 mmhs, whereas Aghbolaghi and Sadeghi (2014) observed that under salinity stress, primed seeds outperformed in terms of the amount of mobilized reserves and seedling dry weight.

The loss of leaf RWC can be associated with the loss of water availability to leaves under salinity stress, or the root systems are unable to replenish the water lost by transpiration due to the decline of water uptake (Smart and Bingham, 1974). The increase in RWC by SA and its derivatives can be related to the role of SA in improving the antioxidant defensive system, alleviating oxidative stress, improving membrane integrity, and adjusting osmosis through increasing potassium content as a vital ion in maintaining cell turgor pressure (Bandurska and Stroinski, 2005; Korkmaz et al., 2007).

SA adjusts cell division by influencing other hormones like auxin, cytokinin, gibberellins, and abscisic acid. It has been reported that this compound increases cell division of apical meristem of primary roots and thereby enhances root elongation (Shakirova et al., 2003). Fariduddin et al. (2003) found that salinity reduces cell division and that SA (antioxidant) could hinder auxin oxidation resulting in higher root and stem dry weight.

Salinity reduces photosystem II activity severely, and the disruption of quinone electron transfer chain, which is related to photosystem II, reduces quantum yield (Lu and Vonshak, 2002). Also, the proteins $\mathrm{D}_{1}$ and $\mathrm{D}_{2}$ of photosystem II are impaired under stressful conditions. These proteins are the main components of this photosystem and their degradation entails photo-inhibition (Bissati et al., 2000; Kruk et al., 2005). SA mitigates this degradation under stressful conditions by accelerating the restoration and conversion of the protein $\mathrm{D}_{1}$ and inducing protein kinases and reversible phosphorylation of proteins (Hui-Jie et al., 2011). Ervin et al. (2005) observed the increase in superoxide dismutase activity after SA treatment of the plants and stated that SA increased the efficiency of photosystem II by activating the antioxidant system and signaling. Salinity adversely affects efficiency and permeability of plasma membrane and cell wall and can disrupt the inflow and outflow of the ions to the cells (Orcutt and Nilsen, 2000). Before the plants are exposed to salinity, SA activates the antioxidative system and it is likely to improve cell membrane and neutralize the risk of ROS buildup when plants are exposed to stress. Consequently, the damage to cell membrane structure and change in its permeability are inhibited under stress conditions. 
Plant growth regulators, such as SA, play their positive role by preventing the damage to fatty acids, the reduction of membrane permeability, and the protection of thylakoid membrane under salinity stress; and these effects are likely to be related to the decrease in the amount of hydrogen peroxide (Borsani et al., 2001).

It was found that all studied traits were influenced by salinity. As salinity level was increased, a decline was observed in germination percentage, germination speed, seed vigor, growth parameters, and the Hill reaction rate and an increase was seen in mean germination time and cell death. SA application improved plant resistance to salinity stress. The treatment of bitter vetch seeds with SA affected germination so that germination-related traits were increased, mean germination time was decreased, growth parameters were improved, the Hill reaction rate was enhanced, and cell death was decreased. At the salinity levels of 50 and $0 \mathrm{mM}$, there was no significant difference between SA rates of 0.2 and 0.1 in germination percentage and mean germination time whereas at these salinity levels, SA rate of $0.2 \mathrm{mM}$ improved other parameters. Plants exposed to $100 \mathrm{mM}$ salinity did not exhibit statistically significant differences in mean germination time and germination speed between SA rates of 0.1 and $0.2 \mathrm{mM}$. Under the salinity level of $100 \mathrm{mM}$, SA rate of $0.1 \mathrm{mM}$ was the best for seed vigor, root length, stem length, seedling length, and seedling dry weight, and SA rate of $0.2 \mathrm{mM}$ was the best for leaf relative water content, seedling fresh weight, root length, stem length, and root and stem fresh weight. At both salinity levels, SA rate of $0.2 \mathrm{mM}$ was related to the highest Hill reaction rate and the lowest cell death. In sum up, seed priming with salicylic acid reduced the detrimental effects of salinity and improved seed vigor and physiological traits.

\section{References}

Abdel-Baki, A. A., \& Anderson, J. D. (1973). Viability and leaching sugars from germinating barley. Crop Science, 10, 31-34.

Abdullah, A. Y., Muwalla, M. M., \& Harb, M. Y. (1999). Evaluation of various protein sources for growing and finishing Awassi lambs. Turkish Journal of Veterinary and Animal Sciences, 23, 475- 482.

Aghbolaghi, M., \& Sedghi, M. (2014). The effect of halo-and hydro-priming on germination characteristics of millet seeds under salinity stress. Cercetari Agronomice in Moldova, 47(2), 41-48.

Akbulut, G. B., Yigit, E., Kaya, A., \& Aktas, A. (2018). Effect af salicylicl acid on organic selenium on wheat (Triticum aestivum L.) exposed to fenoxaprop-p-ethyl. Ecotoxicology and Environmental Safety, 148, 901-909.

Alamri, S. A., Siddiqui, M. H., Al-Khaishani, M. Y., \& Ali, H. M. (2018). Response of salicylic acid on seed germination and physio-biochemical changes of wheat under salt stress. Acta Scientific Agriculture, 2(5), 36-42.

Ashraf, M., \& Foolad, M. R. (2007). Role of glycine betaine and proline in improving plant abiotic stress resistance. Environmental and Experimental Botany, 59(2), 206-216.

Ashraf, M, \& Waheed, A.(1990). Screening of local exotic of lentil (Lens culinaris Medik) for salt tolerance at two growth stage. Plant Soil, 128,167-176.

AOSA. (1983). Seed vigor testing handbook. Contribution 32, Handbook on Seed Testing, AOSA, Lincoln, NE, USA.

Baker, C. J., \& Monck, N. M. (1994). An improved method for monitoring cell death in a cell suspension and leaf disk assays using Evans blue. Plant Cell, 39, 7-12.

Bandurska, H., \& Stroinski, A. (2005). The effect of salicylic acid on barley response to water deficit. Acta Physiologiae Plantarum, 27, 379-386.

Bissati, K. E., Delphin, E., Murata, N., Etienne, A. L., \& Kirilovsky, D. (2000). Photosystem II flouresence - quenching in cyanobacterrium Synechocystis PCC6803: involvement of two different mechanisms. Biochimica Biophysica Acta, 1457, 229-242.

Borsani, O., Valpuestan, V., \& Botella, M. A. (2001). Evidence for a role of salicylic acid in the oxidative damage generated by $\mathrm{NaCl}$ and osmotic stress in Arabidopsis seedlings. Plant Physiology, 126, 1024-1030.

Bradford, K. J. (1995). Water relations in seed germination. In: Kigel J, Galili G (eds.) Seed development and germination Marcel dekkerinc. New York. pp 351-396. 
Brancalion, P. H. S., Novembre, A. D. L. C., Rodrigues, R. R., \& Tay, D. (2008). Priming of Mimosa bimucronata seeds: a tropical tree species from Brazil. Acta Horticulturae, 82, 163-168.

Dai, Q. L., Chen, C., Feng, B., Liu, T., Tian, X., Gong, Y., Sun, Y., Wang, J., \& Du, S. (2009). Effects of different $\mathrm{NaCl}$ concentration on the antioxidant enzymes in oilseed rape (Brassica napus L.) seedlings. Plant Growth Regulation, 59(3), 273-278.

De, F., \& Kar, R. K. (1994). Seed germination and seedling growth of mung bean (Vigna radiate) under water stress induced by PEG-6000. Seed Science and Technology, 23, 301-304.

Ellis, R. A., \& Roberts, E. H. (1981). The quantification of ageing and survival in orthodox seeds. Seed Science and Technology, 9, 373-409.

Eraslan, F., Inal, A,, Gunes, A., \& Alpaslan, M. (2007). Impact of exogenous salicylic acid on the growth, antioxidant activity and physiology of carrot plant subjected to combined salinity and boron toxicity. Scientia Horticulturae, 27, 287-298.

Ervin, E. H., Zhang, X., \& Schmidt, R. E. (2005). Exogenous salicylic acid enhances post-transplant success of heated Kentucky bluegrass and tall fescue sod. Crop Science, 45(1),240-244.

Fariduddin, Q., Hayat, S., \& Ahmad, A. (2003) .Salicylic acid influences net photosynthetic rate, carboxylation efficiency, nitrate reductase activity and seed yield in Brassica juncea. Photosynthetica, 41(2), 281-284.

Foti, R., Abureni, K., Tigere, A., Gotosa, J., \& Gere, J. (2008). The efficacy of different seed priming osmotica on the establishment of maize (Zea mays L.) caryopses. Journal of Arid Environments, 72, 1127-1130.

Gautam, S., \& Singh, P. K. (2009). Salicylic acid induced salinity tolerance in corn grown under $\mathrm{NaCl}$ stress. Acta Physiologiae Plantarum, 31,1185-1190.

Hamid, H., Rehman, K., \& Ashraf ,Y. (2010). Salicylic acid-induced growth and biochemical changes in salt-stressed wheat. Commun. Soil Science and Plant Analysis, 41, 373-389.

Hayat, Q., Hayat, S., Irfana, M., \& Ahmad, A. (2010). Effect of exogenous salicylic acid under changing environment: A review. Environmental and Experimaental Botany, 68, 14-25.

Hendawy, S. F., \& Khalid, K. A. (2005). Response of sage Salvia officinalis L. plants to zinc application under different salinity levels. Journal of Sciences Research, 1(2),147-155.

Hui-Jie, Z., Xue-Juan, Z. H., Pei-Fang, M., Yue-Xia, W., Wei-Wei, H., Hong, L., \& Yi-Dan, Z. (2011). Effects of salicylic acid on protein kinase activity and chloroplast D1 protein degradation in wheat leaves subjected to heat and high light stress. Acta Ecologica Sinica, 31, 259-263.

Katergi, N., Van Horn, J. W., Hamdy, A., Karan, F., \& Mastrovtilli, M. (1994). Effect of salinity on emergence and on water stress early seedling growth of sunflower and maize. Agricultural Water Management, 26, 81-91.

Khan, M. A., \& Ungar, I. A. (1985). The role of hormone in regulating the germination of polymorphic seeds and early seedling growth of Atriplex under saline condition. Acta Physiologiae Plantarum, 63,109-113.

Korkmaz, A., Uzunlu, M., \& Demirkairan, A. R. (2007). Treatment with acetylsalicylic acid protects muskmelon seedlings against drought stress. Acta Physiologiae Plantarum, 29, 503-508.

Kruk, J., Czytko, H. H., Oettmeier, W., \& Trebest, A. (2005). Tocopherol as singlet oxygen scavenger in photosystem II. Plant Physiology, 162, 749-757.

Liu, L., Xia, W., Li, H., Zeng, H., Wei, B., Han, S., \& Yin, C. (2018). Salinity inhibits rice seed germination by reducing $\alpha$-amylase activity via decreased bioactive gibberellin content, Front Plant Science, 9, 275.

Lu, C. M., \& Vonshak, A. (2002). Effect of salinity stress on photosystem II function in cyanobacterial Spirulina platensis cells. Physiologiae Plantarum, 114(3), 405-413.

Orcutt, D. M., \& Nilsen, E. T. (2000). The physiology of plants under stress: soil and biotic factors. John Wiley and Sons, New York. pp 177-235.

Patsikka, .E, Aro, E. M., \& Tyystjarvi, E. (2001). Mechanismm of copper-enhanced photoinhibition in thylakoid membranes. Physiologiae Plantarum, 113,142-150.

Popova, L., Pancheva, T., \& Uzunova, A. (1997). Salicylic acid: properties, biosynthesis and physiological role. Bulgarian Journal of Plant Physiology, 23, 85-93.

Sadeghi, G. H., Pourreza, J., Samie, A., \& Rahmani, H. (2009). Chemical composition and some antinutrient content of raw and processed bitter vetch (Vicia ervilia) seed for use as feeding stuff in poultry diet. Tropical Animal Health and Production, 41, 85-93. 
Shakirova, F. M., Shakbbutdinova, A. R., Bezrukova, M. V., Fatkhutdinova, K. A., \& Fatkhutdinova, D. R. (2003). Changes in the hormonal status of wheat seedling induces by salicylic acid and salinity. Plant Science, 164, 317-322.

Shamsadin Saeid, M., Farahbakhsh, H., \& Maghsodi mod, A. A. (2008). Effects of salinity stress on germination, vegetative growth and some of physiological traits canola cultivars. Science and Technology of Agriculture and Natural Research, 11(41), 191-202.

Sharma, A. D., Thakur, M., Rana, M., \& Singh. K. (2004). Effect of plant growth hormones and abiotic stresses on germination, growth and phosphates activities in sorghum bicolor L. Moench seeds. African Journal of Biotechnology, 3, 308-312.

Smart, R. E., \& Bingham, G. E. (1974). Rapid estimates of relative water content. Plant Physiology, 53, 258-260.

Sudhakar, C., Lakshmi, A., \& Giridarakumar, S. (2001). Changes in the antioxidant enzyme efficacy in two high yielding genotypes of mulberry (Morus alba L.) under $\mathrm{NaCl}$ salinity. Plant Science, 141, 613-619.

Vlot, A. C., Dempsey, D. A., \& Klessing, D. F. (2009). Salicylic acid, a multifaceted hormone to combat disease. Annual Review of Phytopathology, 47,177-206. 